\title{
A Comparison of the Metabolic Response to Phagocytosis in Human Granulocytes and Monocytes
}

\author{
Arthur L. Sagone, Jr., Gerald W. King, and Earl N. Metz \\ From the Division of Hematology and Oncology, Ohio State University \\ College of Medicine, Columbus, Ohio 43210
}

A B S T R A C T Recent studies indicate that oxygen radicals such as superoxide or singlet oxygen may be important in the functional activity of human granulocytes. We have examined the possible importance of these radicals in the functional capacity of human blood monocytes. Monocytes, like granulocytes, generate chemiluminescence during phagocytosis. Chemiluminescence is impaired $50-90 \%$ by superoxide dismutase, an enzyme which enhances the dismutation of superoxide to hydrogen peroxide. These results indicate that superoxide is related to the chemiluminescence generated by monocytes. Superoxide dismutase in a concentration which impaired chemiluminescence also impaired the staphylococcal killing by monocytes. Hexose monophosphate shunt activity and hydrogen peroxide production by granulocytes and monocytes were also evaluated. The oxidation of $\left[1-{ }^{14} \mathrm{C}\right]$ glucose was used as a measure of hexose monophosphate shunt activity and the oxidation of $\left[{ }^{14} \mathrm{C}\right]$ formate as an estimation of hydrogen peroxide production. The oxidation of both substrates by monocytes was increased during phagocytosis but, in contrast to results in granulocytes, was not further increased by the addition of superoxide dismutase.

These data indicate that superoxide may be important in bactericidal activity of human monocytes. Our results also suggest that the metabolism of oxygen radicals in monocytes and granulocytes may be different.

\section{INTRODUCTION}

The importance of the hexose monophosphate shunt and hydrogen peroxide $\left(\mathrm{H}_{2} \mathrm{O}_{2}\right)$ production in the functional capacity of granulocytes is well established $(1,2)$. Recent studies suggest that oxygen radicals other than

This work has been published in abstract form, 1975. Clin. Res. 23: 281A. Dr. Sagone is a scholar of the Leukemia Society of America.

Received for publication 18 August 1975 and in revised form 22 January 1976.
$\mathrm{H}_{2} \mathrm{O}_{2}$, including superoxide $\left(\mathrm{O}_{2}\right)^{1}$ and singlet oxygen, may also be important in the functional capacity of this cell (3-8). The similarity in the metabolic responses of monocytes and granulocytes during phagocytosis (911) raised the possibility that oxygen radicals other than $\mathrm{H}_{2} \mathrm{O}_{2}$ may also be generated in monocytes and contribute to the functional capacity of this cell.

In this study we have investigated the production of oxygen radicals in monocytes during phagocytosis. We have also studied the effect of superoxide dismutase on staphylococcal killing and the hexose monophosphate shunt activity of these cells. Similar studies were done in granulocytes and served as a background for the comparison of the metabolism of these two phagocytic cells. These studies employed the ionization chamber electrometer technique for the continuous measurement of ${ }^{14} \mathrm{CO}_{2}$ so that the time relationships of hexose monophosphate shunt activity, peroxide generation, and $\mathrm{O}_{\overline{2}}$ production during phagocytosis could be studied.

\section{METHODS}

Cell preparation. Venous blood was collected in EDTA from normal healthy volunteers. Mononuclear cells were isolated by the Ficoll-Hypaque technique (12). Platelets were removed by sucrose gradient centrifugation (12). These preparations contained $20-30 \%$ monocytes by morphological criteria and less than $1 \%$ granulocytes. We have previously shown that these morphological evaluations correlate with the functional and membrane characteristics of human blood monocytes (13). This mononuclear cell suspension was used in studies of chemiluminescence, in the bactericidal assay, and in some cases, in the study of glucose metabolism. In addition, monocyte monolayers of $95 \%$ purity were formed in glass metabolic flasks as previously described (13). In some experiments, pure lymphocyte suspensions were obtained as previously described by preincubation of the blood with iron particles before the Ficoll-Hypaque separation (14). This results in a mononuclear suspension which is greater than $99 \%$ lymphocytes as determined by

${ }^{1}$ Abbreviations used in this paper: $\mathrm{CL}$, chemiluminescence; HMPS, hexose monophosphate shunt ; $\mathrm{O}_{\overline{2}}$, superoxide; SOD, superoxide dismutase. 
morphological criteria. Granulocytes were isolated by dextran sedimentation (15). The granulocytes were further purified by Ficoll-Hypaque gradient centrifugation to remove contaminating mononuclear cells. The final preparation contained greater than $90 \%$ granulocytes, less than $10 \%$ erythrocytes, and less than $1 \%$ mononuclear cells.

Glucose metabolism. The production of ${ }^{14} \mathrm{CO}_{2}$ by granulocyte suspensions, monocyte suspensions, and monocyte monolayers was measured continuously using the ionization chamber-electrometer method as previously described (16$20)$. Monocyte monolayers prepared from $1-2 \times 10^{7}$ mononuclear cells in 25-ml triple-headed distilling flasks were incubated in $4 \mathrm{ml}$ of Earle's balanced salt solution with $50 \mathrm{mg} / 100 \mathrm{ml}$ of glucose supplemented with amino acid and vitamins (MEM vitamins and amino acid, Gibco Diagnostics, The Mogul Corp., Chagrin Falls, Ohio), 1\% antibiotic solution $(200,000 \mathrm{U}$ penicillin $\mathrm{G}, 100 \mathrm{mg}$ streptomycin), and $5 \mu \mathrm{Ci}$ of $\left[{ }^{14} \mathrm{C}\right]$ glucose or $\left[{ }^{14} \mathrm{C}\right]$ formate. In some cases, $2 \times 10^{7}$ mononuclear cells were studied in suspension. In granulocyte experiments $1-2 \times 10^{7}$ cells were studied in suspension. The inlet of the metabolic flask was connected to a gas cylinder containing compressed air with $5 \% \mathrm{CO}_{2}$. The outlet arm of the flask was connected to a 275-ml CaryTolbert ionization chamber and a Cary model 401 vibrating reed electrometer (Cary Instruments, Fairfield, N. J.). The third arm of the flask was covered with a rubber stopper through which reagents could be added or samples withdrawn through a spinal needle. A duplicate system was used so that ${ }^{14} \mathrm{CO}_{2}$ derived from $\left[1-{ }^{14} \mathrm{C}\right]$ glucose substrate could be measured simultaneously from both control and experimental flasks. The incubation flasks were stirred continuously. After base line $\mathrm{CO}_{2}$ production was established, opsonized zymosan particles were added in $0.4 \mathrm{ml}$ of normal saline $\left(4 \times 10^{8}\right.$ particles $\left./ \mathrm{ml}\right)$. In studies in which the effects of enzymes were determined, the enzymes were added in $0.1 \mathrm{ml}$ of buffer or sterile water before the addition of the zymosan particles. An equal volume of buffer, bovine serum albumin, or heat denatured superoxide dismutase was added to the controls. The superoxide dismutase was denatured by boiling for $30 \mathrm{~min}$. $\mathrm{CO}_{2}$ production was calculated from the millivolt reading and expressed as nanomoles of $\mathrm{CO}_{2}$ produced per hour per $10^{7}$ cells.

Cells were counted electronically using a model FN Coulter Counter (Coulter Electronics Inc., Hialeah, Fla.). The number of monocytes in the monolayer was determined from the DNA content of the monolayers (21).

Chemiluminescence assay. Chemiluminescence was studied using a Packard model 3225 liquid scintillation counter (Packard Instrument Co., Inc., Downers Grove, III.) in a darkroom as described by Webb et al. (5). Approximately $1 \times 10^{7}$ mononuclear cells or granulocytes were suspended in $6.6 \mathrm{ml}$ of Earle's balanced salt solution containing vitamins and amino acids in siliconized liquid scintillation counting vials. The vials were wrapped in aluminum foil and stored in the dark for at least $12 \mathrm{~h}$ before use. Zymosan was added in $0.4 \mathrm{ml}$ of saline, as in the experiments involving glucose metabolism. Enzyme was added in $0.1 \mathrm{ml}$ of buffer before the addition of the phagocytic particles. A similar volume of buffer or buffer with bovine serum albumin was added to the control vials. In some experiments, heat denatured superoxide dismutase was employed as a control in order to exclude a nonspecific protein effect of the enzyme.

Bactericidal activity. Bactericidal activity was determined by a method reported previously (22). Briefly, mononuclear preparations containing $2.5 \times 10^{\circ}$ monocytes were mixed by rotation at $37^{\circ} \mathrm{C}$ with $12.5 \times 10^{\circ}$ Staphylococcus aureus in $1 \mathrm{ml}$ of Hank's balanced salt solution containing $10 \% \mathrm{AB}$ serum. The number of viable staphylococci was determined at zero time, $30 \mathrm{~min}$, and $1 \mathrm{~h}$ by triplicate colony counts. The results were expressed as number of organisms killed in $30 \mathrm{~min}$ or $1 \mathrm{~h}$. As we have previously reported, lymphocytes do not exhibit bactericidal activity (22).

Materials. Superoxide dismutase $(3,000 \mathrm{U} / \mathrm{mg})$ was purchased from Truett Labs, Dallas, Tex. Its activity was checked with xanthine and xanthine oxidase according to the method of McCord and Fridovich using horse-heart ferricytochrome $c$ (type IV-Sigma Chemical Co., St. Louis, Mo.) (23). $\left[{ }^{14} \mathrm{C}\right]$ Glucose substrates were purchased from Amersham/Searle Corp., Arlington Heights, Ill. $\left[{ }^{14} \mathrm{C}\right]$ Formate $(50 \mu \mathrm{Ci} / \mu \mathrm{m})$ was purchased from New England $\mathrm{Nu}-$ clear, Boston, Mass. In some cases, small quantities of volatile radioactive materials were found in the radioactive materials and were removed by gassing before the addition of other reagents. Twice recrystallized beef catalase $(30,000$ $40,000 \mathrm{U} / \mathrm{mg}$ ) and zymosan were purchased from Sigma Chemical Co. Zymosan particles were opsonized in freshfiltered AB sera as described by Webb et al. (5).

Statistical analysis. Data were analyzed according to the $t$ test for independent samples (24).

\section{RESULTS}

Granulocyte metabolism. Fig. 1 illustrates the time relationship of the enhanced $\left[1-{ }^{14} \mathrm{C}\right]$ glucose and $\left[{ }^{14} \mathrm{C}\right]-$ formate oxidation occurring during phagocytosis using the continuous method for measuring ${ }^{14} \mathrm{CO}_{2}$. Both $\left[1-{ }^{14} \mathrm{C}\right]$ glucose oxidation and formate oxidation increased almost immediately after the addition of opsonized zymosan particles and reached a maximum value at about the same time. In eight experiments, the peak value for $\left[1-{ }^{14} \mathrm{C}\right]$ glucose oxidation was achieved by $27.7 \pm 3.8 \mathrm{~min}(\mathrm{SD})$ compared to $23.9 \pm 4.1 \mathrm{~min}(\mathrm{SD})$ for $\left[{ }^{14} \mathrm{C}\right]$ formate oxidation $(P, \mathrm{NS})$.

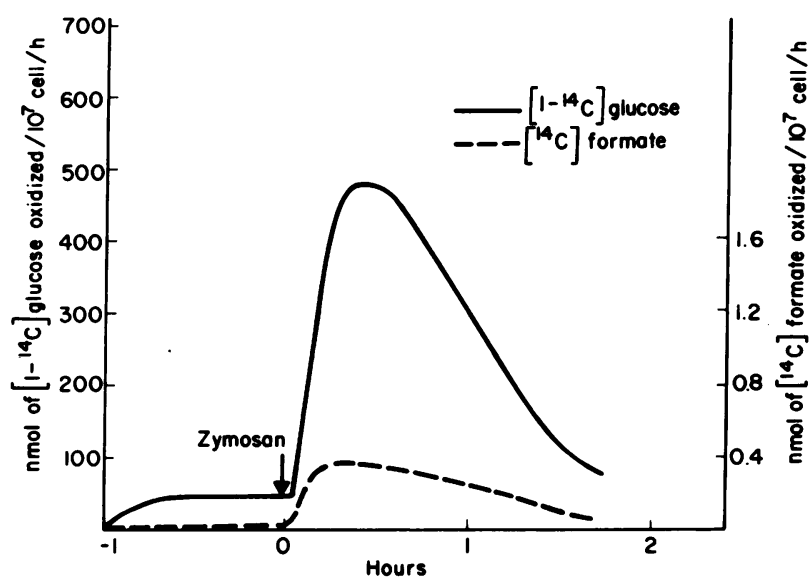

FIGURE 1 Oxidation of ${ }^{14} \mathrm{C}$-substrate by granulocytes. The curves represent a continuous measurement of ${ }^{14} \mathrm{CO}_{2}$ by granulocyte suspensions. After steady-state conditions were established, the addition of opsonized zymosan particles, as indicated by the arrow, results in a prompt increase in both $\left[1{ }^{14} \mathrm{C}\right]$ glucose and $\left[{ }^{14} \mathrm{C}\right]$ formate oxidation. Results of a single experiment are illustrated but are representative of over 40 performed. 


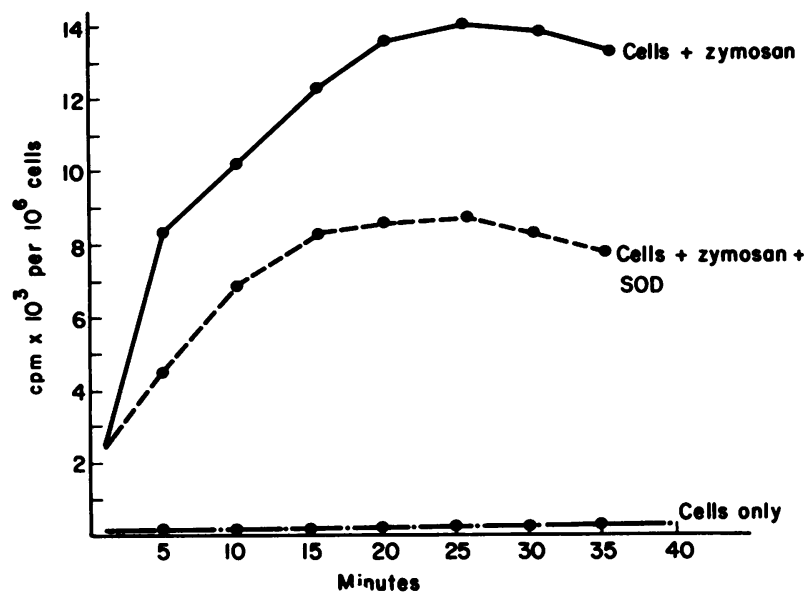

Figure 2 The rate of generation of $\mathrm{CL}$ by granulocytes during the phagocytosis of opsonized zymosan particles. Experimental measurements (๑) were made every $5 \mathrm{~min}$. (-) indicates the CL of controls in the presence of $z y-$ mosan. Little spontaneous $\mathrm{CL}$ occurred in resting cells $(\cdot--\cdot) .10 \mu \mathrm{g} / \mathrm{ml}$ SOD $(---)$ impaired CL. A representative experiment is shown. This inhibition ranged from 31 to $80 \%$ in five paired experiments (mean $52 \pm 18$ ).

The curve indicating the generation of chemiluminescence $(\mathrm{CL})$ during the phagocytosis of zymosan particles is illustrated in Fig. 2. It is of interest that this curve has a pattern similar to that found for both [1$\left.{ }^{14} \mathrm{C}\right]$ glucose oxidation and $\left[{ }^{14} \mathrm{C}\right]$ formate oxidation. Superoxide dismutase in a concentration of $10 \mu \mathrm{g} / \mathrm{ml}$ inhibited the CL of granulocytes during phagocytosis (Fig. 2). This concentration of superoxide dismutase resulted in enhanced oxidation of $\left[1-{ }^{14} \mathrm{C}\right]$ glucose. A typical experiment is illustrated in Fig. 3. In four paired experiments, the mean maximum rate of $\left[1-{ }^{14} \mathrm{C}\right]$ glucose oxidation of suspensions incubated with superoxide dismutase (SOD) was $709 \pm 60 \mathrm{nmol} / 10^{7}$ cells per $\mathrm{h}(\mathrm{SD})$ compared with $535 \pm 95 \mathrm{nmol} / 10^{7}$ cells per $\mathrm{h}(\mathrm{SD})$ in controls $(P<0.05)$. An increased oxidation of $\left[{ }^{14} \mathrm{C}\right]-$ formate and $\left[2-{ }^{14} \mathrm{C}\right]$ glucose also occurred in suspensions incubated with SOD compared to controls without the enzyme. In contrast, no significant increase in the oxidation of $\left[6-{ }^{14} \mathrm{C}\right]$ glucose occurred indicating that the increased $\left[1{ }^{14} \mathrm{C}\right]$ glucose oxidation was due to increased hexose monophosphate shunt (HMPS) activity and not the result of increased Krebs cycle activity.

${ }^{2}$ Enhanced production of ${ }^{14} \mathrm{CO}_{2}$ from $\left[2{ }^{14} \mathrm{C}\right]$ glucose indicates that the stimulation of the HMPS by SOD results also in an increased feedback of pentose through the HMPS via the transketolase and transaldolase reactions. This control is necessary to rule out the possibility that SOD might inhibit feedback of pentose through the HMPS, thus increasing the oxidation of $\left[1-{ }^{14} \mathrm{C}\right]$ glucose without a net increase in HMPS activity (16).
Monocyte metabolism. The pattern of oxidation of $\left[1-{ }^{14} \mathrm{C}\right]$ glucose by monocyte monolayers during phagocytosis was similar to that of granulocytes (Fig. 4). In contrast to experiments with granulocytes, the oxidation of $\left[{ }^{14} \mathrm{C}\right]$ formate was more difficult to demonstrate in that the monocytes of some normal persons produced only a small increase in $\left[{ }^{14} \mathrm{C}\right]$ formate oxidation. Further, detection of the oxidation of formate after the addition of the zymosan was often somewhat delayed compared to the oxidation of $\left[1{ }^{14} \mathrm{C}\right]$ glucose (Fig. 4). Since catalase is required for the oxidation of formate in the presence of $\mathrm{H}_{2} \mathrm{O}_{2}$, catalase was added to the incubation to determine if this would enhance $\left[{ }^{14} \mathrm{C}\right]$ formate oxidation. The pattern of $\left[{ }^{14} \mathrm{C}\right]$ formate oxidation in the presence of catalase was similar to that of $\left[1-{ }^{14} \mathrm{C}\right]$ glucose (Fig. 4). Studies were also done with mononuclear suspensions containing both monocytes and lymphocytes with similar results.

The generation of CL during phagocytosis by monocyte suspensions is illustrated in Fig. 5. These experiments used $1 \times 10^{7}$ mononuclear cells with $20-30 \%$ monocytes. In seven paired experiments the addition of SOD resulted in $50-90 \%$ reduction in CL similar to the results with granulocytes. The addition of boiled dismutase in three paired experiments reduced CL only 2-9\% (mean 6\%) compared to the controls. This latter observation indicates a requirement for active enzyme. In contrast to results with granulocytes, incubation of

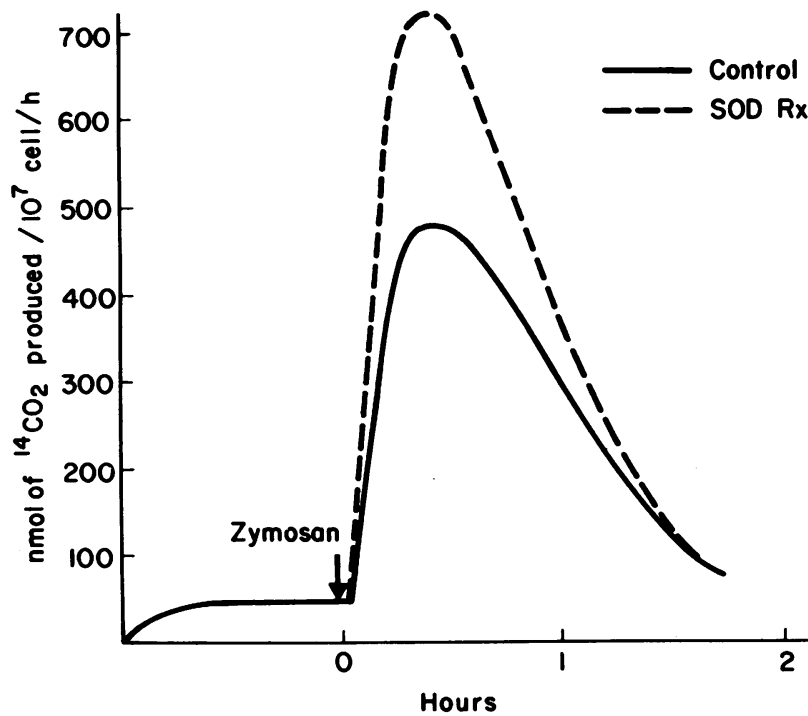

FIgURE 3 The effect of SOD on the oxidation of $\left[1-{ }^{14} \mathrm{C}\right]-$ glucose by granulocytes. The curves represent the result of one of the four paired experiments which were performed. The suspensions with $10 \mu \mathrm{g} / \mathrm{ml}$ SOD $(----)$ and the control (-) are given. The maximum value from each curve was used to calculate the mean for the four experiments. The values are given under Results. 


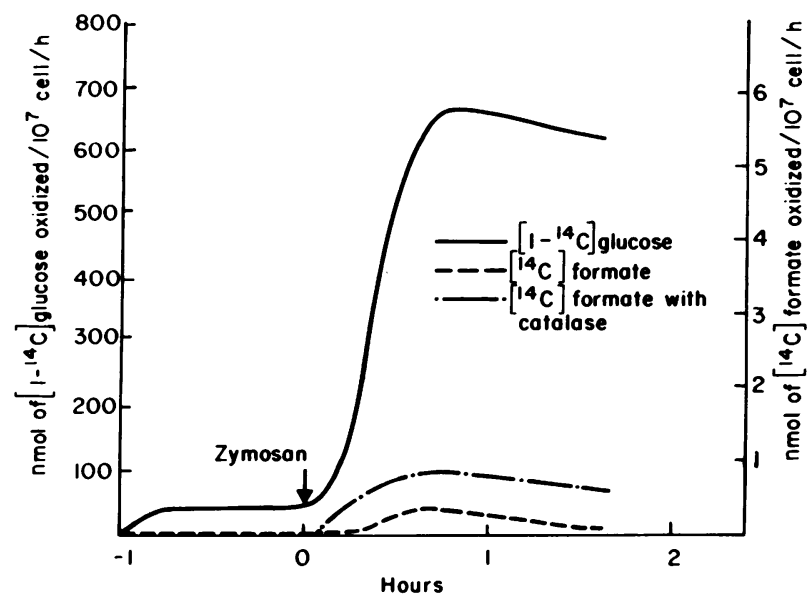

FIGURE 4 The oxidation of ${ }^{14} \mathrm{C}$-substrate by monocyte monolayers. The curves represent a continuous measurement of ${ }^{14} \mathrm{CO}_{2}$ production from $\left[1-{ }^{14} \mathrm{C}\right]$ glucose $(-)$ and $\left[{ }^{14} \mathrm{C}\right]$ formate (-- - ). The curves were drawn using the data points from a single experiment and are representative of over 20 performed. After steady-state conditions were established, zymosan was added as indicated by the arrow. The addition of catalase $(20 \mu \mathrm{g} / \mathrm{ml})$ enhanced the oxidation of $\left[{ }^{14} \mathrm{C}\right]$ formate $(\cdot--\cdot)$.

monocyte monolayers or mononuclear suspensions with SOD did not significantly alter $\left[1-{ }^{14} \mathrm{C}\right]$ glucose during phagocytosis (Table I). Similarly, the rate of $\left[{ }^{14} \mathrm{C}\right]-$ formate oxidation was not changed by SOD. In three paired experiments, the mean maximum rate of $\left[{ }^{14} \mathrm{C}\right]-$ formate oxidation during phagocytosis by mononuclear suspensions incubated with SOD was $0.38 \pm 0.03 \mathrm{nmol} /$ $10^{7}$ cells per $\mathrm{h}(\mathrm{SD})$ compared to $0.44 \pm 0.04 \mathrm{nmol} / 10^{7}$ cells per $\mathrm{h}(\mathrm{SD})$ for controls $(P>0.2)$. Results using

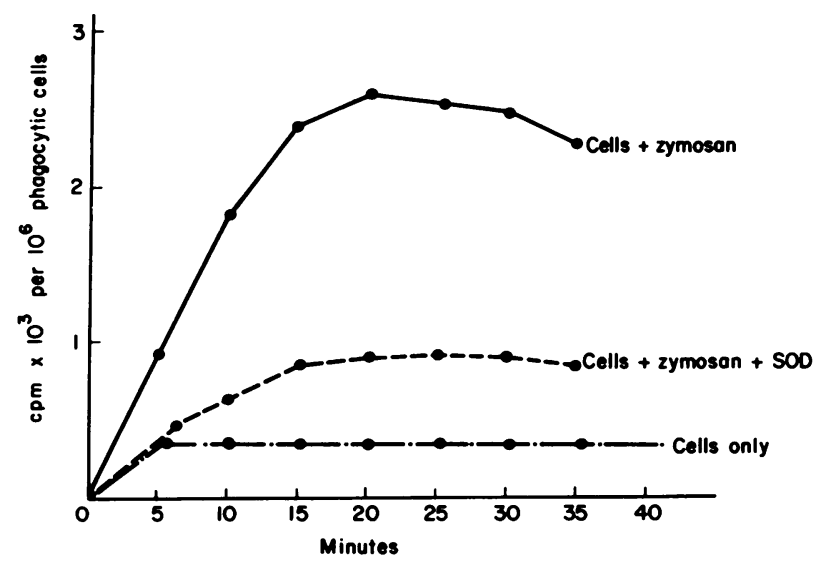

FIGURE 5 The rate of generation of CL by mononuclear cell suspensions. The results indicate a single experiment in which $\mathrm{CL}$ was measured every $5 \mathrm{~min}(\bullet) . \mathrm{CL}$ by mononuclear suspensions with buffer is indicated (-). The addition of SOD resulted in impaired $C L$ and ranged from 50 to $82 \%$ in seven paired experiments (mean $66 \pm 10$ ).
TABLE I

Effect of SOD on $\left[1{ }^{14} \mathrm{C}\right]$ Glucose Oxidation by Mononuclear Suspensions during the Phagocytosis of Zymosan

\begin{tabular}{lcc}
\hline & Cell + zymosan & Cells + zymosan + SOD \\
\hline Mean & $321^{*}$ & $288^{*}$ \\
SD & \pm 104 & \pm 106 \\
Number & 6 & 6
\end{tabular}

* Values are in $\mathrm{nmol} / 10^{7}$ monocytes per $\mathrm{h}$ and were calculated from the maximum HMPS activity occurring after the addition of the zymosan particles. The curves for $\left[1-{ }^{14} \mathrm{C}\right]$ glucose oxidation are illustrated in Fig. 4. $P$ value is not significant.

formate plus SOD were similar with and without supplemental catalase.

Bactericidal activity. Incubation of mononuclear suspensions with SOD resulted in a significant impairment of staphylococcal killing at both 30 and 60 min compared to controls (Fig. 6). We did not find it necessary to coat latex particles with SOD in order to demonstrate a significant impairment in bactericidal activity by SOD as was found by others in a study of granulocytes (8).

Comparison of the CL of granulocytes and monocytes. In order to determine if there were quantitative

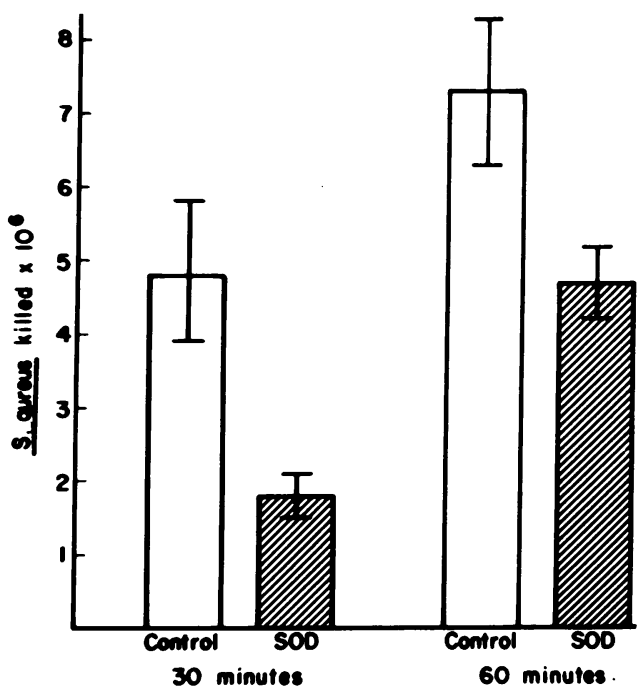

FIgURE 6 Effect of SOD on the bactericidal capacity of monocytes. The results represent the mean of three experiments. The mean $( \pm S D)$ of the control suspensions is indicated by the solid bars. The mean $( \pm S D)$ of suspensions incubated with SOD $(10 \mu \mathrm{g} / \mathrm{ml})$ is indicated by the stippled bars. The scale at the left of the figure indicates the absolute number of organisms killed of the $12.5 \times 10^{6}$ added to the incubation. Killing was impaired by SOD at both 30 and $60 \mathrm{~min}$. Values at both times are significantly different with $P$ values of less than 0.02 . In the absence of cells, and in the presence or absence of SOD, there was no significant change in the number of bacteria at 30 or 60 min compared to the number added at the beginning of the incubation. 
differences in CL produced by granulocytes and monocytes, the CL of these two cell types from a single donor was studied simultaneously. Isolated cells were resuspended in $6.6 \mathrm{ml}$ of Hank's balanced salt solution as described above with the exception that granulocyte suspensions were diluted so that the final concentration was equal to that of the monocytes. The CL generated by each suspension after the addition of $0.4 \mathrm{ml}$ of opsonized particles was then measured every $5 \mathrm{~min}$. The maximum CL for each curve was determined and this value used to compare the CL generated by each suspension. The mean $\pm \mathrm{SD}$ for paired experiments using cells from four different donors is given in Fig. 7. The amount of CL generated by granulocytes was fivefold higher than the CL generated by monocytes when given an equivalent load of zymosan particles.

Since the monocyte $\mathrm{CL}$ studies were done with lymphocytes in the incubation, further control experiments were performed to exclude the possibility that lymphocytes might interfere with the CL generated by the monocytes. This could be a result of a nonspecific protein effect or a result of enzyme activity in these cells. To test this possibility, the effect of lymphocyte contamination on granulocyte $\mathrm{CL}$ was examined. Granulocytes and lymphocytes were isolated from the same donor and the CL of granulocyte suspensions to which lymphocytes were added was compared to that of pure granulocyte suspensions. Pure lymphocyte preparations

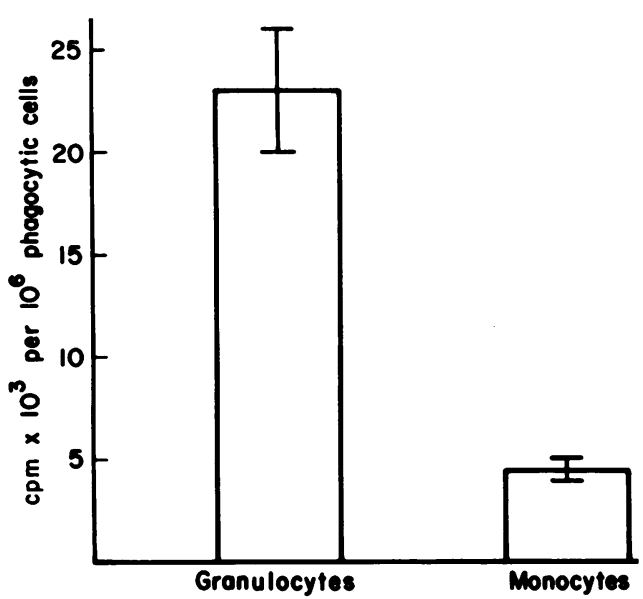

Figure 7 Comparison of the CL of monocyte and granulocytes. The results represent the means $\pm S D$ of four paired experiments in which the maximum CL generated by granulocytes and monocytes during the phagocytosis of zymosan particles were compared. The maximum CL generated was determined by maximum value on the rate curves illustrated in Figs. 2 and 5. The bar at the left indicates the mean values for granulocytes and is fivefold higher than the value for monocytes indicated by the bar at the right of the figure $(P<0.01)$. The particle to cell ratio was approximately 30 to 1 .
TABLE II

Effect of Lymphocytes on the CL of Granulocytes

\begin{tabular}{lcc}
\hline & Granulocytes alone & Granulocytes + lymphocytes \\
\hline Mean & $23.7^{*}$ & $22.8^{*}$ \\
SD & \pm 3.2 & \pm 5.6 \\
Number & 4 & 4 \\
\hline
\end{tabular}

* Values are given in $\mathrm{cpm} \times 10^{3}$ per $10^{6}$ granulocytes and represent the maximum $C L$ generated after the addition of zymosan. The curves showing the rate of generation of $\mathrm{CL}$ are illustrated in Fig. 2. $P$ value is not significant.

were prepared using iron particles as described under Methods. Lymphocytes were added to granulocytes so that the final ratio of lymphocytes to granulocytes was similar to the lymphocyte to monocyte ratio in our mononuclear suspensions. The absolute number of granulocytes used was also equivalent to the number of monocytes studied. In four paired experiments using cells from four different donors, the generation of CL by granulocyte suspensions supplemented with lymphocytes was similar to that of the granulocytes alone (Table II). This observation indicates that lymphocytes in our mononuclear preparations did not interefere with the $\mathrm{CL}$ measurement. We also confirmed the observation of Allen et al. (6) that lymphocytes do not generate CL when incubated with zymosan.

\section{DISCUSSION}

Our results confirm the observations of Webb et al., which indicate that the $\mathrm{CL}$ generated by granulocytes during the phagocytosis of zymosan particles is impaired by SOD (5). These investigators have also established that this phenomenon clearly requires active enzyme and that it cannot be attributed to a nonspecific effect such as altered phagocytosis (5).

Our experiments show that human monocytes also generate CL during phagocytosis. The fact that this phenomenon in both cells is markedly inhibited by SOD, a specific scavenger of $\mathrm{O}_{2}(25)$, indicates that $\mathrm{O}_{2}$ is related to this reaction. It is possible that other radicals are, in turn, generated from $\mathrm{O}_{\overline{2}}(5,6)$ and the direct effect of singlet oxygen and hydroxyl radicals on $\mathrm{CL}$ remains to be determined. The same concentration of SOD which impaired CL also significantly altered the bactericidal activity of monocytes at both 30 and $60 \mathrm{~min}$. Thus, it is clear that $\mathrm{O}_{\overline{2}}$ is important in the functional activity of human monocytes as it is in granulocytes. Recently, Drath and Karnovsky have suggested that $\mathrm{O}_{\overline{2}}$ may also be important in the functional capacity of some animal macrophages (26).

The above results might be interpreted, as suggested by other investigators, that the biochemical reactions occurring during phagocytosis are quite similar for monocytes and granulocytes (10-12). Our studies sug- 
gest, however, that there may be some important differences in these two phagocytic cells. The major differences relate to the effect of SOD on HMPS activity during phagocytosis and the unpredictability of formate oxidation in monocytes. In granulocytes, the generation of $\mathrm{H}_{2} \mathrm{O}_{2}$ and the stimulation of the HMPS appear to be closely related biochemical events which begin almost immediately after the addition of particles. As did Baehner et al., we found that all of these events are modified considerably by the addition of SOD (7). The increase in HMPS activity and in formate oxidation in the presence of SOD indicates that the dismutase reaction has resulted in an increased rate of conversion of $\mathrm{O}_{\overline{2}}$ to peroxide which is then detoxified via catalase or peroxidases linked to the HMPS (7). Likewise, the data can be interpreted as indicating that normally, i.e. in the absence of supplemental SOD, some of the $\mathrm{O}_{\overline{2}}$ generated during phagocytosis is not converted to intracellular peroxide and enters into other reactions. The precise nature of these reactions is uncertain, but the impairment of bactericidal capacity of granulocytes (8) in the presence of SOD must certainly be a clue to potential sites of action for this radical.

In monocytes, the pattern of glucose oxidation during phagocytosis appeared similar to that in granulocytes. As in granulocytes, staphylococcal killing was also impaired by SOD. However, in monocytes the burst of formate oxidation was unpredictable and frequently required the addition of supplemental catalase for its demonstration. Furthermore, the addition of SOD to the incubation mixture did not result in augmentation of HMPS activity in response to phagocytosis. These data suggest that in monocytes there may be alternate pathways for the detoxification or utilization of oxygen radicals generated during phagocytosis.

One possible explanation for this difference in formate oxidation in monocytes would be that monocytes are relatively deficient in catalase. This enzyme is necessary for the oxidation of formate by peroxide (27) and, indeed, our experiments show that formate oxidation was somewhat increased in monocytes by the addition of supplemental catalase. On the other hand, even with supplemental catalase present, we were unable to show an additional augmentation of formate oxidation with SOD as was observed in granulocytes. A more attractive explanation for the differences in both formate oxidation and the failure of SOD to augment HMPS activity in monocytes is that $\mathrm{O}_{2}$ is involved in other reactions in monocytes. In this regard, Tyler has demonstrated that $\mathrm{O}_{\overline{2}}$ is utilized in the peroxidation of the lipid membrane in mitochondria (28). Recently, Stossel et al. have shown a similar reaction in the membrane of monocytes during phagocytosis, a biochemical reaction which did not occur in granulocytes without the ad- dition of linolenate as a substrate for the peroxidative reaction (29).

The relative amounts of oxygen radicals generated during a phagocytic load and the degree to which these radicals are detoxified within the cell may have important implications regarding the ability of these two phagocytic cell lines to kill specific organisms.

\section{ACKNOWLEDGMENTS}

This work was supported by a grant from the National Institutes of Health, 5 RO1-CA-13381. The authors are indebted to Mrs. Susan Kamps, Rosemary Husney, Robert Campbell, and Geraldine Bain for technical assistance, and Helen Ilc for manuscript preparation.

\section{REFERENCES}

1. Klebanoff, S. J. 1975. Antimicrobial mechanism in neutrophilic polymorphonuclear leukocytes. Semin. Hematol. $12: 117-142$.

2. Sbarra, A. J., B. B. Paul, A. A. Jacobs, R. R. Strauss, and G. W. Mitchell, Jr. 1972. Biochemical aspects of phagocytic cells as related to bacterial function. $J$. Reticuloendothel. Soc. 11: 492-502.

3. Babior, B. M., R. S. Kipnes, and J. T. Curnutte. 1974. Biological defense mechanisms. The production by leukocytes of superoxide, a potential bactericidal agent. $J$. Clin. Invest. 52 : 741-744.

4. Curnutte, J. T., D. M. Whitten, and B. M. Babior. 1974. Defective superoxide production by granulocytes from patients with chronic granulomatous disease. $N$. Engl. J. Med. 290: 593-597.

5. Webb, L. S., B. B. Keele, Jr., and R. B. Johnston, Jr. 1974. Inhibition of phagocytosis-associated chemiluminescence by superoxide dismutase. Infect. Immun. 9: 1051-1056.

6. Allen, R. C., R. L. Stjernholm, and R. H. Steele. 1972. Evidence for the generation of an electronic excitation state(s) in human polymorphonuclear leukocytes and its participation in bactericidal activity. Biochem. Biophys. Res. Commun. 47: 679-684.

7. Baehner, R. L., S. K. Murrmann, J. Davis, and R. B. Johnston, Jr. 1975. The role of superoxide anion and hydrogen peroxide in phagocytosis-associated oxidative metabolic reactions. J. Clin. Invest. 56: 571-576.

8. Johnston, R. B., Jr., B. B. Keele, Jr., H. P. Misra, J. E. Lehmeyer, L. S. Webb, R. L. Baehner, and K. V. Rajagopalan. 1975. The role of superoxide anion generation in phagocytic bactericidal activity. Studies with normal and chronic granulomatous disease leukocytes. J. Clin. Invest. 55: 1357-1372.

9. Root, A. K., A. S. Rosenthal, and D. J. Balestra. 1972. Abnormal bactericidal, metabolic, and lysosomal functions of Chediak-Higashi syndrome leukocytes. J. Clin. Invest. 51: 649-665.

10. Cline, M. J., and R. I. Lehner. 1968. Phagocytosis by human monocytes. Blood. 32: 423-435.

11. Baehner, R. L., and R. B. Johnston, Jr. 1972. Monocyte function in children with neutropenia and chronic infections. Blood. $40: 31-41$.

12. Perper, R. J., T. W. Zee, and M. M. Mickelson. 1968. Purification of lymphocytes and platelets by gradient centrifugation. J. Lab. Clin. Med. 72: 842-848.

13. Koller, C. A., G. W. King, P. E. Hurtubise, A. L. Sagone, and A. F. LoBuglio. 1973. Characterization of 
glass adherent human mononuclear cells. J. Immunol. $111: 1610-1612$.

14. Rinehart, J. J., A. L. Sagone, S. P. Balcerzak, G. A Ackerman, A. F. LoBuglio. 1975. Effects of corticosteroid therapy on human monocyte function. $N$. Engl. $J$. Med. 292: 236-241.

15. Johnston, R. B., Jr., M. R. Klemperer, C. B. Alper, and F. S. Rosen. 1969. The enhancement of bacterial phagocytosis by serum. The role of complement components and two cofactors. J. Exp. Med. 129: 1275-1290.

16. Sagone, A. L., E. N. Metz, and S. P. Balcerzak. 1972. Effect of inorganic phosphate on erythrocyte pentose phosphate pathway activity. Biochim. Biophys. Acta. $261: 1-8$.

17. Metz, E. N., and A. L. Sagone, Jr. 1972. The effect of copper on the erythrocyte hexose monophosphate shunt pathway. J. Lab. Clin. Med. 80: 405-413.

18. Chaudhry, A. A., A. L. Sagone, Jr., E. N. Metz, and S. P. Balcerzak. 1973. Relationship of glucose oxidation to aggregation of human platelets. Blood. 41: 249-258.

19. Sagone, A. L., Jr., A. F. LoBuglio, and S. P. Balcerzak. 1974. Alterations in hexose monophosphate shunt during lymphoblastic transformation. Cell. Immunol. 14: 443452.

20. Sagone, A. L., Jr., S. P. Balcerzak, and E. N. Metz. 1975. The response of red cell hexose monophosphate shunt after sulfhydryl inhibition. Blood. 45: 49-54.

21. Prasad, A. S., E. DuMouchelle, D. Koniuch, and D.
Oberleas. 1972. A simple fluorometric method for the determination of RNA and DNA in tissue. J. Lab. Clin. Med. 80: 598-602.

22. Rinehart, J. J., S. P. Balcerzak, A. L. Sagone, and A. F. LoBuglio. 1974. Effects of corticosteroids on human monocyte function. J. Clin. Invest. 54: 1337-1343.

23. McCord, J. M., and I. Fridovich. 1969. Superoxide dismutase. An enzymatic function for erythrocuprein ( $\mathrm{He}$ mocupreine). J. Biol. Chem. 244: 6049-6055.

24. Worcester, J. 1966. The statistical method. N. Engl. J. Med. 274: 27-36.

25. Hodgson, E. K., and I. Fridovich. 1974. The production of superoxide radical during the decomposition of potassium peroxochromate (V). Biochemistry. 13: 38113815.

26. Drath, D. B., and M. L. Karnovsky. 1975. Superoxide production by phagocytic leukocytes. J. Exp. Med. 141: 257-262.

27. Klebanoff, S. J., and S. H. Pincus. 1971. Hydrogen peroxide utilization in myeloperoxidase-deficient leukocytes: a possible microbicidal control mechanism. $J$. Clin. Invest. 50: 2226-2229.

28. Tyler, D. D. 1975. Role of superoxide radicals in the lipid peroxidation of intracellular membranes. FEBS (Fed. Eur. Biochem. Soc.) Lett. 51: 180-183.

29. Stossel, T. P., R. J. Mason, and A. L. Smith. 1974. Lipid peroxidation by human blood phagocytes. J. Clin. Invest. 54: 638-645. 